\title{
Chen Lai, Tradition and Modernity: A Humanist View
}

translated by Edmund Ryden, Leiden/Boston, Brill, 2009, 386 pp.

\section{Selena Dramlic}

\section{(2) OpenEdition}

\section{Journals}

\section{Electronic version}

URL: http://journals.openedition.org/chinaperspectives/5761

DOI: 10.4000/chinaperspectives.5761

ISSN: 1996-4617

\section{Publisher}

Centre d'étude français sur la Chine contemporaine

\section{Printed version}

Date of publication: 30 December 2011

Number of pages: 75-76

ISSN: 2070-3449

\section{Electronic reference}

Selena Dramlic, «Chen Lai, Tradition and Modernity: A Humanist View », China Perspectives [Online], 2011/4 | 2011, Online since 30 December 2011, connection on 22 September 2020. URL : http:// journals.openedition.org/chinaperspectives/5761; DOI : https://doi.org/10.4000/chinaperspectives. 5761

This text was automatically generated on 22 September 2020 .

(c) All rights reserved 


\section{Chen Lai, Tradition and Modernity: A Humanist View}

translated by Edmund Ryden, Leiden/Boston, Brill, 2009, 386 pp.

\section{Selena Dramlic}

This book is the first comprehensive English-language translation of key academic works by Chen Lai (陈来) - a leading mainland philosopher and Dean of Tsinghua University's Guoxue Research Institute (清华国学研究院). The collection brings together writings produced in the dramatic decade beginning with 1988. Together the chapters provide deep insight into the ways that one of China's key contemporary intellectuals has grappled with the question of how to best utilise China's traditional culture for the nation's modernising aspirations. The tension encapsulated in a tradition-modernity duality has dominated many of China's best minds for long stretches of the last century. Chen's book provides us with insights into how that binary was

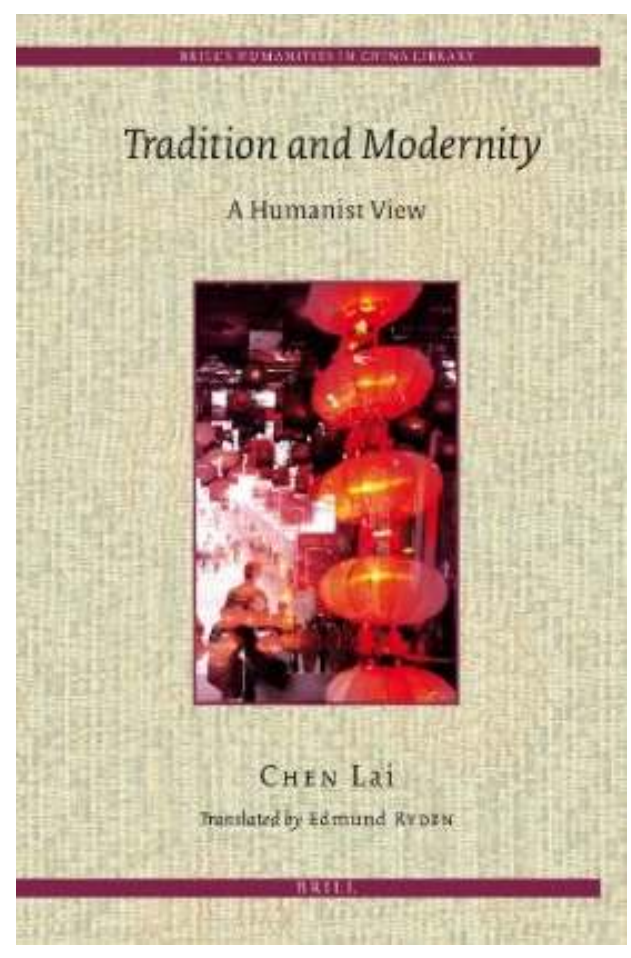
understood in the rapidly changing years of Deng Xiaoping's market reforms. In the introduction to the book Chen leaves no room for misunderstanding his motivation, declaring, "The main focus of this book is the significance of the tradition of Confucian values in contemporary society" (p. 1). Chen's attention to this question has lost none of its urgency as Confucius has become 
an international and domestic icon for the soft power and "harmonious society" campaigns of the $\mathrm{Hu}$ Jintao era.

One of Chen's major themes is the way that cultural conservatives reacted to the iconoclastic May Fourth New Culture Movement and its active denigration of Confucianism. In Chapters 2, 3, and 4 Chen explores the distinctions between the cultural conservatives and the cultural radicals that dominated the traditionmodernity debate in early twentieth-century China and ultimately sides with the conservatives' view for their appreciation of traditional culture's value to a modern and modernising China. Without diminishing the May Fourth New Culture Movement's many significant contributions to China's modernity and the nation's development processes, Chen revisits the May Fourth's "mainstream" cultural thought and reevaluates its radical rejection of tradition. The author identifies cultural utilitarianism as the major flaw of intellectual thought in the May Fourth New Culture period. To Chen, cultural utilitarianism is the rejection of traditional culture based upon the utilitarian norms that judge any "aspect of human culture that is not directly related to strengthening the working of political economy [as] valueless" (p. 83). The May Fourth radicals' negative appraisal of Confucianism emerged from within this utilitarian thinking, and in contrast to their views Chen argues that traditional Chinese Confucian values are indispensible to modern Chinese society. Chen's logic is that an economy without a core moral code produces a fragmented society. To justify this position, he makes frequent references to Christianity and its demonstrated capacity to provide core cultural continuity in Western nations despite the vast social changes they have experienced. Chen writes that Christianity, with all the changes it has experienced through history, continues to be "...the source of values for existence and for affirming the course of life for modern western civilization." (p.59). Following this line of reasoning, Chen believes that the Confucian value system should be accepted as a spiritual resource and accommodated as part of modern Chinese cultural fabric as well.

Chen analyses the Confucian tradition from diverse perspectives and multiple angles. He discusses the basic ideas and concepts of Confucian philosophy in Chapter 14. The importance of Confucian values to the modernisation of East Asia and to modern China's transformation is explored in Chapters 9 and 10, respectively. In each of these chapters Chen aspires to demonstrate the importance of Chinese traditions, as represented by the Confucian value system, to China and the Asian region. He proposes a formula for future Chinese cultural development in Chapter 16, suggesting the following model:"Pushing ahead by absorbing Western culture; pulling forward by exalting Chinese culture." In Chen's opinion, China needs to continue absorbing Western culture, but should develop simultaneously "a good cultural nominal system, critically inheriting the past, creatively transforming traditional culture, especially the value system of traditional culture." This envisioned cultural system should also include "values of socialism, Marxism in modern Chinese culture..." (pp. 352-353). Chen's cursory description of the actual processes of "critical inheritance" and "creative transformation" leaves readers pondering the multifaceted and somewhat contradictory dimensions of this hybrid cultural form - but the primacy of Confucianism is never in doubt. Moreover, Chen presents Confucianism as a potential moral foundation for Chinese socialism and not only Chinese culture, mirroring his idea that Christianity underpinned the progress of Western civilisation. In this rubric, little or no attention is given to the impact of other religious or cultural systems on either 
China or "the West." The search for a single moral code to guide both individual behaviour and national governance in China underpins Chen's logic. The author's optimism about the significance of traditional Confucian values is encapsulated in his statement that what China offers to humanity in the twenty-first century is precisely its traditional cultural legacies: "Benevolence as substance and harmony as means."

Chen's volume also introduces readers to a key platform for the rehabilitation of Confucius in China today - guoxue (national learning/studies, 国学). This branch of academic research has evolved into a popular cultural movement yet has only recently started drawing the focused attention of the academic community outside of China (see China Perspectives No. 1, 2011). In a chapter with the lengthy title of "The Difficulty of Undertaking National Studies Research in the Nineties: The Problem of the National Studies Fever and Research into Traditional Culture," readers are provided with an important and authoritative study of guoxue. Presented at a conference in 1994 and first published in 1995, this article is one of Chen's early analyses of the guoxue phenomenon. The chapter commences with an overview of events at Peking University in late 1993, generally regarded as the starting point for broad academic discussion on guoxue. The public nature of the academic debate in turn generated widespread popular interest in Chinese traditions and together ignited the so called guoxue craze (国学热). Chen suggested that the craze was "encouraged by media whilst the ceremonies to remember Confucius were arranged and conducted by the Party" (p. 334). Although Chen Lai remains rather sceptical of the genuine usefulness of the guoxue craze for enhancing academic research, he proposes that the "fever" should be regarded as having a tight connection to Deng Xiaoping's famous "Southern Tour" of 1992, which subsequently led to official endorsement of the socialist market economy system. He writes: "Indeed, the propagation of national studies fever in the latter half of 1993 might be seen as the product of a reaction against the counter-example set by the irrational commercialisation that surged because of the market economy. (...) The socalled national studies fever of 1993 can be read as a form of resistance by academic scholarship to the shock of commercialisation" (p. 344). The chapter also contains Chen's examination of the etymology of the term guoxue that simultaneously provides a short overview of guoxue's historical development. Amidst tortured academic debates about the precise nature of guoxue, Chen posits the view that guoxue is "quite simply the idea of 'traditional Chinese culture'." He also notes possible ideological collisions that arise from the guoxue revival - on the political level with Marxism, and on the intellectual level with the "dominant enlightenment liberalism and closed dogmatism" - both legacies of the May Fourth Movement. Consistent with the tone of the entire collection, Chen Lai is optimistic about guoxue's (or traditional Chinese culture's) future prospects and anticipates the revitalisation and reconstruction of China's national spirit (p.347). Just as Tradition and Modernity tended to conflate Chinese tradition with Confucianism, in academic debates about guoxue "national learning" is likewise frequently used as a synonym for Confucianism.

5 This collection also includes several book reviews and in-depth studies of the works of key cultural and philosophical thinkers from China and beyond. In Chapter 6, Chen discusses Liang Shuming's (1893-1988) ideas on culture as espoused in his Eastern and Western Cultures and their Philosophies, and later, in Chapter 13, compares Liang's thought system to Weber's in a detailed analysis. The author also analyses Feng Youlan's (1895-1990) philosophical system (in Chapters 7 and 8), Bellah's Tokugawa Religion: The Cultural Roots of Modern Japan (Chapter 11), and the scholarship of Thomas Metzger 
(Chapter 12). These chapters demonstrate Chen Lai's deep knowledge of and engagement with Western scholarship and provide a significant point of comparison for his comments on China.

In sum, mainland China in the late 1980s-early 1990s experienced a major revival of interest in traditional culture, including the academic re-evaluation of its validity and rekindled popular interest in various traditional legacies. This trend shows no signs of abating any time soon. One manifestation of this cultural shift has been a renewed academic enquiry into the Chinese past that often critically re-evaluates the hitherto unproblematised impact of the May Fourth thinkers.Chen Lai's Tradition and Modernity provides a convenient avenue through which English reading audiences can appraise this critical scholarly re-evaluation and understand how socialism and Marxism are integrated into this heady mix. Chen's proposed cultural model is meant to "... consolidate in a stable fashion a socialism with chinese cultural characteristics and a complete market economy" (p. 353). Despite oftentimes referring to "traditional Chinese culture" and its value system, it seems that Chen's view of tradition is exclusively linked to Confucianism. Chen does explicitly point to his stance and motivation at the beginning of the book by saying that his goal is to confirm Confucian values - a key notion that brings together all the essays of this collection. It would nevertheless be interesting to read whether any other traditional Chinese values (beyond the Confucian) have anything to offer to modern Chinese society or humanity.

Edmund Ryden's translator's notes are an important addition to this wonderfully translated volume. To those interested in acquiring more detailed background knowledge on the issues raised in Tradition and Modernity, Ryden's annotations provide a useful guide. They simultaneously clarify possible "less-known" facts and events, thus ensuring that the book is accessible to the general reader and experts alike. The appearance of Chen Lai's work in English will enable a broader reading audience to understand the ongoing process of China's modernisation as it inevitably propels academic and popular reappraisals of that nation's long cultural heritage.

\section{AUTHOR}

\section{SELENA DRAMLIC}

PhD Candidate in Modern China Studies at the School of Modern Languages and Cultures, The University of Hong Kong. 